\title{
Cardiac Tricuspid Valve Repair
}

National Cancer Institute

\section{Source}

National Cancer Institute. Cardiac Tricuspid Valve Repair. NCI Thesaurus. Code C99935.

Surgery performed for the purpose of reducing regurgitation of the cardiac valve between the right atrium and right ventricle. (ACC) 